\title{
NATIONAL NEWSPAPERS' ROLE IN NATIONAL INTEGRATION AND THEIR COVERAGE OF ETHNIC ISSUES IN KARACHI
}

\author{
Imtiaz Ahmad* \\ Tahir Masood**
}

\begin{abstract}
The research aims to see as to how identity discourse of national dallies contributes to the process of national integration by analyzing newspapers' coverage of ethnic issues in the communally-battered Karachi. For the purpose, two major Urdu and English newspapers in Jang and Dawn published in 2007, 2008 and 2009 are selected for textual analysis; with the May 12, 2007 ethnic carnage being in spotlight. The findings are a mixed bag containing both positives and negatives. Apart from increased realization in discourse of both dailies that ethnicity is a problem, Dawn has got no place for nationalistic rhetoric based on one Islamic identity which may have positive implications for national integration. Nonetheless, Jang, as per the findings, is yet to wean itself off the nationalistic rhetoric.
\end{abstract}

Keywords: Nationalism, ethnicity, framing, integration, newspapers, discourse

\section{Introduction}

National integration has always been a huge problem in Pakistan. Whether it is the issues of religious minorities or the problems faced by linguistic minorities represented by small provinces, the Pakistani state is yet to give full constitutional rights to its minorities. It's, in fact, these feelings of deprivation on part of the linguistic minorities mainly Pakhtuns, Sindhis and Balochs which are the main stumbling block in the way of national integration.

The dominance of ethnic groups like ethnic Punjabis and Urdu-speaking Mohajirs in the pre-1971 era and their strong belief in and subsequent promotion of state nationalismone language Urdu and one religion Islam - has led to ethnic nationalisms which was bound to hamper the process of national integration. The dominant groups have used textbooks as well as media including newspapers to promote the state nationalism leading sometimes to even extreme ethnic nationalisms. With the focus of attention being communally battered Karachi wherein violence like the May 12, 2007 ethnic carnage was a routine matter until recently, the issue at hand is to see how the press dealt with the process of national integration.

\section{National integration vs. ethnic nationalism}

Firstly, with the state being in spot light, it must be mentioned that all states are reflections of power. Power existence starts to appear when two people establish a

\footnotetext{
* Imtiaz Ahmad, Ph.D. student, Department of Mass Communication, University of Karachi

*** Tahir Masood, Ph.D. Professor, Department of Mass Communication, Karachi University
} 
relationship which alters their positions physically and mentally. For instance, if agent $\mathrm{A}$, having influence over agent $\mathrm{B}$, we may say agent $\mathrm{A}$ will have power over B. But the relationship, according to a viewpoint, would be weak if A coerces B into submission. "Thus a powerful relationship is one whereby agents A and B agree on fundamentals setting forth their unequal equation". ${ }^{1}$ Hence, power as a relationship based on consent "is the ability to influence in a legitimate manner so that the complying agent accepts to change position peacefully though not necessarily happily." In other words, as Ahmed argues, "power exists when compliance can be exacted".

The state is controlled by ruling classes who abuse their power. Nonetheless, to achieve the level of 'power as a relationship based on consent' there are devices like constitution which curbs power abuses. ${ }^{3}$ As for exacting compliance, the state does two things in this regard: A. It concentrates on "ideology, political socialization, political participation, the distribution of socio-economic benefits." B. It focuses on having "punitive intelligence gathering and military capacities to exact compliance". ${ }^{4}$

Shedding light on nationalism, nationalism is all about "attitudes and beliefs" of those who live in their own state or those who aspire to achieve their own state to practice their 'belief' there. On the other hand, Ito (1999) quotes Kajita as saying:

Ethnicity... refers to the attitudes and belief of people who don't necessarily demand separation, independence or their own home country. Generally speaking, therefore, 'nationalism' is a problem between people with their own territories, whereas the 'ethnicity' is a problem between people within the same territory. 5

Also, Ito quoting Anderson says nationalism and ethnicity are same, for former is "like an older brother of ethnicity;" with "nationalism belongs (ing) to the majority and ethnicity to the minority." And once it is decided by the minority (ethnicity) to have its own state, its struggle becomes ethnic nationalism and belief and ideals practiced by it in their own state after achieving it is called state nationalism. As per Adeel, nationalism cannot exist without state. ${ }^{7}$ The notion of 'nation-state' insinuates congruence between both but it hardly happens amid ethnic minorities. Those having an easy access to the state or dominating it are harbingers of state nationalism while those having difficulties in accessing to it launch ethnic nationalism. ${ }^{8}$ It is important we refer to Breuilly quoted

\footnotetext{
${ }^{1}$ I. Ahmed, "Ethnicity, State, Society and Nation," in State, Nation and Ethnicity in Contemporary South Asia (London: Printer, 1996), 27.

${ }^{2}$ Ahmed, State, "Nation and Ethnicity in Contemporary South Asia", 27 onwards.

${ }^{3}$ S. Rajagopalan, State and Nation in South Asia (Lynne Rienner Publisher Inc, 2001).

${ }^{4}$ I. Ahmed, "Ethnicity, State, Society and Nation," in State, Nation and Ethnicity in Contemporary South Asia (London: Printer, 1996), 30 \& 31.

${ }^{5}$ Y. Ito, "Theories on the Mass Media and Ethnicity: How do the Mass Media Affect Ethnicity and Related Problems?," in Mass Media and Cultural Identity: Ethnic Reporting in Asia, ed. A. Goonasekera and Y. Ito (London: Pluto Press, 1999), 18.

6 Ito "Mass Media and Cultural Identity," 17.

${ }^{7}$ A. Khan, "Ethncity, Nationalism and the Modern State," in Politics of Identity: Ethnic Nationalism and the State in Pakistan (Sage Publication, 2005), 29.

${ }^{8}$ Ibid.
} 
by Ahmed, according to whom nationalism, power and state are all connected. Ahmed while quoting Breuilly maintains: "Nationalism is above all and beyond all else about politics and that politics is about power. Power in the modern world, is primarily about control of the state".

A multi-ethnic state, according to Kazi, is always faced with integration issues. The state nationalism promoted by the multi-ethnic state usually takes one of the two paths: either it opts coercive ways to integrate groups or goes for 'unity in diversity' policy. ${ }^{10}$ However, most of the developing multi-ethnic states have hardly opted for any 'unity in diversity' policy, for, barrowing Rajagopalan's words, ${ }^{11}$ the only thing the state cares for is the centrality of history and the multi-ethnic state in this regard is no exception. The modern state including Pakistan is faced with this enigma and to solve this riddle it ends up in violence against dominated groups.

\section{State nationalism, ethnic nationalism (s) and national integration in Pakistan}

Whether it's (state) nationalism or ethnic nationalism, there remains the state at the heart of both. It was the British who introduced the modern state in India following the 1857 Mutiny after which the colonizers launched themselves through the instrument of state which co-opted various ethnic groups while excluding others. It's this policy of inclusion and exclusion which had great implications for the ethnic groups of Pakistan as well as Pakistani state. Punjabi and UP's Muslim elites, who migrated to Pakistan, had always been in collusion with the British. The Punjabi landlords got close to the British after the 1857 Mutiny with the former offering help to imperialists in war. On the other hand, earlier, there had been deep collaboration between Muslim UP elites and the British while, later on, the British had had on side UP's landlord Leaguers. Such collaboration ensured Upite elites their jobs despite being a tinny minority. Having hands in glove with the British, the two groups in Punjabis and Mohajirs had a great representation in the affairs of the British with the successor Pakistani state also being dominated by the same groups.

Two dominant platforms in Pakistan Muslim League and Pakistan military were having huge impact on political affairs of the newly-created state and both the civilian and military organizations were dominated by Punjabis and Mohajirs, respectively. Hence nationalism promoted by the state in the pre-1971 era was not the one representing "attitudes and beliefs" of the majority_oppressed Bengalis_-and was not based on "attitudes and beliefs" shared by other groups of the then West Pakistan but was based on "attitudes and beliefs" of two minority groups in Mohajirs and Punjabis who left no stone unturned in oppressing other linguistic groups due to which the latter launched their own ethnic nationalisms to make the state either responsive to their demands or achieve their own state.

\footnotetext{
${ }^{9}$ I. Ahmed, "Ethnicity, State, Society and Nation," in State, Nation and Ethnicity in Contemporary South Asia (London: Printer, 1996), 11.

${ }^{10}$ Ahmed, State, "Nation and Ethnicity in Contemporary South Asia", 9.

${ }^{11}$ S. Rajagopalan, State and Nation in South Asia (Lynne Rienner Publisher Inc, 2001)
} 
Though Pakhtun ethnic nationalism, according to Feroz Ahmed ${ }^{12}$ (1998), had had its roots in pre-partition India and, according to the work of Adeel Khan (2005), is linked to Pakhtun anti-colonial nationalism launched by Ghaffar Khan in mid 1920s, Sindhi ethnic nationalism was a reflection of a sense of deprivation felt by Sindhi leadership during the clumsy integration process initiated by Punjabi and Mohajir elites. On the other hand, it must be stated that identity is fluid and depends on group's access to socio-economic means embodied by the state. This phenomenon was reflected in post1971 when the country was dismembered and ethnic Punjabis became the sole majority now needing no support of Urdu-speakers who until this time had a rapidly decreasing share in civil and military bureaucracies. Pakhtuns on their part had a steady presence since colonial era in army. It was actually, Pakhtuns' large presence in military, which caused a change in their loyalties, with a shift from their ethnic to state nationalism taking place, thus becoming partners of Punjabis. ${ }^{13}$

However, Pakhtuns are yet to be fully integrated into the Pakistani state amid burning issues of FATA and PATA. Also, unsuccessful efforts in connection with the process of national integration have dawned on all and sundry in Sindh capital which every now and then erupts into violence. Karachi violence is also the result of, among other factors, failure of linguistic groups to reach any power-sharing deal a phenomenon linked with the state's unsuccessful integration policy.

\section{National integration and newspapers}

With critical theory in mind to understand the role of press in national integration, it is time to dwell on relationship between printed words and identity politics. Concepts of state, nation, nationalism and national integration are deeply connected with those of language, printed words / typography and communication technologies and have historically been in a sort of 'cause and effect' relationship. McLuhan's following statement just illuminates this relationship.

... The typographic explosion extended the minds and voices of men to reconstitute the human dialogue on a world scale that has bridged the ages. For, if seen merely as a store of information, or as a new means of speedy retrieval of knowledge, typography ended parochialism and tribalism, physically and socially, both in space and time. ${ }^{14}$

On the other hand, Benedict Anderson being more direct in his approach expresses the view that typography is at the heart of modern 'nation,' with the European continent witnessing the fixation of languages in the wake of print-capitalism taking place after the middle of the second millennium. Anderson while connecting language, which, as per Richardson, is social and 'a kind of dialogue with the society' ${ }^{15}$ and contributes to

\footnotetext{
${ }^{12}$ F. Ahmed, Ethnicity and Politics in Pakistan (New York: Oxford University Press, 1998).

13 A. Khan, Politics of Identity: Ethnic Nationalism and the State in Pakistan (Sage Publication, 2005).

${ }^{14}$ M. McLuhan, The Printed Word: Architect of Nationalism (New York: McGraw-Hill Book Company, 1964), 170

15 J. E. Richardson, "Introduction: Newspapers Discourse," in Analysing Newspapers: an Approach from Critical Discourse Analysis (Palgrave Macmillan, 2007), 10.
} 
the reproduction of social reality/social word, print-capitalism - the capitalist enterprise of book-publishing - and the concept of nation in order to make a point for 'the origin of national consciousness,' argues that "print-capitalism gave a new fixity to language, which in the long run helped to build that image of antiquity so central to the subjective idea of the nation." 16 Anderson's view of fixation of language carries weight, for Ito (1999) also argues that distinction among languages in the pre-print Europe was difficult but not after the emergence of typography "making linguistic boarder clear, which later helped form and solidify nation-states and maintain nationalism all over Europe". ${ }^{17}$ Summing up the discussion, today's modern state has been once again faced with the implications of language use - newspapers discourse - for various linguistic groups existing in the multi-ethnic state.

Language as mentioned in the above lines is social and it's actually its 'social-ness' which not only reflects identities of speakers but also others' "expectations as to what speakers intend to accomplish in a particular act of communication". ${ }^{18}$ And this is the expectations or institutional expectations we have from the language use-discourse (of newspapers) - " when we pick up a newspaper or a magazine, that it will be written in a particular way". ${ }^{19}$ Notwithstanding the 'institutional expectations' that one harbors about language use - discourse of newspapers - one cannot ignore the fact that discourse cannot be 'accurate' always as traditional media academicians in Pakistan usually emphasize. This is what an authority says while stating that news is not what we see in newspaper in its final shape but passes many frames including "cultural, legal, political, technical and commercial interests". ${ }^{20}$

There are several factors which influence the selection and shaping of news. "A variety of factors influence the selection and shaping of news stories: from fairness and objectivity to deadlines, from political views of owners, managers and journalists to transmission cost; from financial interests of advertisers to ethnic and linguistic prejudices of owners, journalists, readers and viewers; from modern communications technologies to stakeholders' return". ${ }^{21}$ Reese, Gandy and Grant have expressed the same views, stating: "Framing is concerned with the way interests, communicators, sources, and culture combine to yield coherent ways of understanding the world, which are developed using all of the available verbal and visual symbolic resources". ${ }^{22}$

${ }^{16}$ B. Anderson, "The Origin of National Consciousness," in Imagined Communities (Verso, 2006), 44.

17 Anderson, "Imagined Communities," 17.

${ }^{18}$ J. E. Richardson, "Introduction: Newspapers Discourse," in Analysing Newspapers: an Approach from Critical Discourse Analysis (Palgrave Macmillan, 2007), 10.

${ }^{19}$ Richardson, "Analysing Newspapers," 44.

20 A. Goonasekera, "News as a Social Construct,” Media Asia 1992, no. 19 (1992): 9 \& 10.

${ }^{21}$ Goonasekera, "Media Asia," 10.

22 "Prologue - Framing Public Life: a Bridging Model for Media Research," in Framing Public Life: Perspectives on Media and our Understanding of the Social World, ed. S. D. Reese, O. H. Gandy, and A. E. Grant (London: Lawrence Erlbaum Associates, Publishers, 2001), 11. 
Also, the dominance of a particular sectarian/ethnic group in newsroom is a frame any discourse goes through having implications for integration in a country like Pakistan. ${ }^{23}$ Morley quoted by Reese, Gandy and Grant also refers to 'the basic conceptual and ideological framework' 'through which events are presented and as a result of which they come to be given one dominant/primary meaning rather than another". ${ }^{24}$ Though the framing concept is connected to media discourse, it is hardly given any importance as a result of which media narrative is only reflective of one particular interpretation. Say editors of 'Framing Terrorism': "The essence of framing is selection to prioritize some facts, images, or developments over others, thereby unconsciously promoting one particular interpretation of events". ${ }^{25}$ The issue of dominant discourse does not only prevail in developing states but the developed world is also faced with the same problem, with the US struggling to integrate its White and Black population, for instance. Nonetheless, academia in the developed world has been aware of the issue of dominant discourse with Robert M. Entman while analyzing electronic media coverage of White and Black population arguing that White dominance in the US media discourse prevents an ethnically-balanced coverage of issues with regard to White and Black peoples in electronic media.

Comparing news of victimization with regard to White and Black population in the US, Entman argues in the light of his findings that the electronic media gave more airtime to White victims than Black ones.

Another way of comparing news of victimization is length of time devoted to the story: the average story featuring Black victims was 106 seconds long; those featuring White victims, 185 seconds long. Using total story time as a measure, the ratio of time spent on White victims to that on Blacks exceeded $3: 1{ }^{26}$

On the other hand, there is hardly any organized study dealing with ethnic issues' coverage by media in Pakistan, though extensive works have been conducted on ethnic issues. It's not to insinuate in any way that there is no literature on media coverage of ethnic issues in Pakistan but the fact is that the same issue of lack of literature on coverage of ethnic issues in Pakistan was faced during the course of this author's Ph.D. thesis titled 'Newspapers Coverage of Ethnic issues in Karachi.' One of the reasons behind the lack of any work on the coverage of ethnic issues by media/newspapers may be the dominance of certain ethnic groups in Pakistani/Karachi's newspapers who are hardly attentive to the issue of coverage of other linguistic groups. This is what is argued in the abovementioned thesis:

\footnotetext{
${ }^{23}$ K. Ahmed, "Introduction," in Sectarian War: Pakistan Sunni-Shia Violence and its Links to the ME (Karachi: Oxford University Press, 2011), Xxv \& xxvi.

24 "Prologue — Framing public Life: a Bridging Model for Media Research," in Framing Public Life: Perspectives on Media and our Understanding of the Social World, ed. S. D. Reese, O. H. Gandy, and A. E. Grant (London: Lawrence Erlbaum Associates, Publishers, 2001), 10.

25 "Generating Terrorism Frames," in Framing Terrorism the News Media, the Government and the Public, ed. P. Norris, M. Kern, and M. Just (London: Routledge, 2003), 11.

${ }^{26}$ R. M. Entman and A. Rojecki, "Violence, Stereotypes, and African-Americans in the News," in The Black Image in the White Mind: Media and Race in America (Chicago and London: The University of Chicago Press, 2000), 81.
} 
There may be many reasons for the lack of ... work on the issue but the chief being the dominance of Punjabis and Mohajirs in both print and electronic media who rarely feel the issue of covering other ethnic groups in the media partly due to their strong belief in the composition of the present state arena which suits them unlike Pakhtuns, Sindhis, Baloch, etc who are either secessionists at extreme level or simply unhappy with the present state arena". ${ }^{27}$

\section{Research methodologies}

Ethnic inequality has led to the feelings of deprivation among linguistic minorities of Pakistan who have launched movements of ethnic nationalisms with bleak situation of ethnic imbalance hitting hard Sindh capital Karachi which is faced with a double-edged sword in post-1971 era; with the province, on one hand, resisting a challenge to its territorial sovereignty in shape of a belligerent Mohajir ethnic nationalism while, on the other, the land of Sufis has a long struggle against a powerful centre. The identity discourse does give the impression that the dominant narrative is hardly challenged but there also hardly exist any data endorsing the abovementioned assumption. The research aims to see as to how newspapers discourse treats identity issues in Karachi and whether it contributes to the process of nation-building.

Since the aim is to analyze discourse in connection with the coverage of ethnic issues in Sindh capital Karachi, it seems important to single out any one occasion of ethnic violence and its coverage by English and Urdu newspapers. With Karachi often taking a plunge into ethnic clashes until recently, ethnic mayhem occurred on May 12, 2007 is one such occasion when violence hit the city after clashes between representative parties of Sindhis, Mohajirs and Pakhtuns. With both English and Urdu newspapers, published after May 12 carnage, representing the most natural units of analysis, textual analysis of newspapers of 2008 and 2009 has also been carried out to obtain a representative data.

With the research aiming to investigate newspapers discourse by finding out between the lines message and extracting any hidden meaning in the news discourse, we also need a qualitative research methodology in discourse analysis which is all about "dig (ing) deep into the meaning of a particular text". ${ }^{28}$ On other hand, we also do need a quantitative research methodology in shape of content analysis, which "involving counting and measuring quantities of items such as words, phrases or images... will allow us to look across a large number of texts"29 ("Discourse analysis and content analysis," 2006) which will help in broad generalization of data.

With Dawn and Jang being chosen as sample units-due to their respective largest English and Urdu readers apart from being epitomes of English and Urdu journalism, respectively, in Pakistan - taken from population comprising Karachi's almost all major English and Urdu newspapers, the method of random sampling was carried out in connection with the time period of 2007, 2008 and 2009 selected for textual analysis.

${ }^{27}$ I. Ahmad, "Newspapers' Coverage of Ethnic Issues in Karachi," (PhD diss., University of Karachi, 2017).

28 "Discourse Analysis and Content Analysis," in Analyzing Media Texts, ed. M. Gillespie and J. Toynbee

(New Delhi: Tata McGraw Hill Education Private Limited, 2006), 120.

29 “Analyzing Media Texts," 120 
With exception of year 2007, considering occurrence of the ethnic carnage on May 12, 2007, any four months of 2008 and 2009 are analyzed while every fourth day's news content was perused through.

With May 13, 2007 being starting point for textual analysis, rest of three months in 2007 as well as four months each of 2008 and 2009 have been chosen on the basis of random sampling method. It must be mentioned that the focus of attention is those ethnic news items published on city, front and back pages with only those news being taken into consideration having any relationship to identity politics.

The identity discourse carried by Jang and Dawn has been divided into two categoriesCategory First and Category Second - on the basis of content source with Category First having the content generated by reporters but having no bylines. Such content is usually titled as 'By Our Reporter/Correspondent' etc. On the other hand, Category Second contains news items with exclusive bylines with the same category also containing content generated through press releases or news agencies.

\section{Data codification}

To have a comprehensive discourse analysis news discourse has been analyzed from the following angles which, in connection with discourse analysis, are our codes.

1. Event and statement: As the following tables show, the code/angle namely 'event' and statement help in understanding whether any particular news item is eventbased or statement-based.

2. Exclusive news [exc]: To have any clue whether a reporter made any special efforts to cover any ethnic news the code in exclusive news has been developed.

3. Is ethnicity a problem? Whether the journalistic discourse considers ethnicity or existence of different languages which result in ethnic turmoil a problem?

4. Ethnic context: If name of any ethnic group either appears in the content or any issues related to any group, it has been dealt as news discourse written in the 'ethnic context.'

5. Unity in diversity: Whether the news items deal with Karachi's ethnic affairs as an ethnic problem which needs to be dealt with through proper power-sharing deal among various linguistic groups which in turn leads to 'unity in diversity' in the city.

6. Two-nation theory/Pakistan ideology: The news content falling in this category will be the discourse which is related to unity of peoples on the basis of the controversial two-nation theory which is against any other identities except for the Islamic one.

7. Ethnic preference/tilt: Whether the discourse shows any tilt to any particular ethnic group. 
8. Solution: Any remedial steps discussed in the context of transport issues, encroachments and land grabbing among other problems has been treated as a code namely 'solution.'

9. Community condemned: Whether news items used any negative adjectives without attributing them to proper witness accounts or other reliable sources.

10. Ethnic actors: The discourse analysis will also help extract which ethnic actors are named in the discourse.

11. Ethnic conflict: The code is about any news story which contains conflict or bad relations between various ethnic groups.

12. Ethnic relations: This code is about news content containing both bad and good relations among communities. This particular code is also about those news items which cherish Karachi's multi-lingual legacy.

13. Human touch: The codification aims to see whether a reporter has got any broad knowledge of issues related to migration like, for example, his awareness about the causes of migration which might be global warming, inter-state conflicts and natural calamities among others.

14. Incitement to violence: The code has been formulated about the discourse which does not deal with issues in line with the law but calls for violence.

15. Quota condemned: Karachi's politics has long revolved around the quota system this time in favour of old Sindhis which was resented by Mohajirs. Discourse condemning the quota system has been given a code called quota condemned

16. Mohajir integration and Mohajir separatism: Any news item which discusses the integration of Mohajirs is coded as 'Mohajir integration,' while Mohajirs' separatist tendencies has been coded as 'Mohajir separatism.'

17. Provincial autonomy favoured: This particular code in 'provincial autonomy favoured' is about the discourse which contains any semblance of tendencies towards advocating the issue of provincial autonomy.

18. Provincial autonomy condemned: The code is the opposite of the previous code in 'provincial autonomy favoured.'

19. Politics of ethnicity: The code deals with the discourse containing discussion on relations between provinces, issues of small provinces apart from Punjab's dominance about which usually small provinces complain.

\section{Comparison between Jang and Dawn}

Before we make any further move to compare the discourses of Dawn and Jang, it must be mentioned here that first an effort has been made to find out aggregate percentage points of all categories/codes of English daily Dawn and Urdu daily Jang published in 
2007, 2008 and 2009. Hence comparison has been done on the basis of aggregated percentage points.

Getting down to the data presented in table 1, it can easily be grasped that Jang's aggregate average number of ethnic news items published per year in the Category First - news content generated by reporters but having no bylines - are more than Dawn, with the Urdu daily carrying an aggregate average of 56 ethnic news items against 29.67 carried by Dawn while the same is the case with the Category Second - news content with bylines as well as news items generated through press releases or news agenciesdepicted in table 2 wherein Dawn carried aggregate average of 32.67 against quite a larger aggregate average number of 52.35 news carried by Jang. Jang carried more statements than Dawn as reflected in table 1 with Dawn carrying 31.68 aggregate percentage points against Jang's mammoth 55.31 aggregate percentage points in the Category First (clearly defined in the above lines).

\section{Table 1 \\ CATEGORY FIRST}

[Reporters' content without bylines]

\begin{tabular}{|c|c|c|}
\hline \multicolumn{3}{|c|}{$\begin{array}{c}\text { AGGREAGTE \% AGE ETHNIC ACTORS CATEGORY } \\
\text { FIRST 2007, 2008, 2009 } \\
\end{array}$} \\
\hline & \multicolumn{2}{|c|}{ NEWS } \\
\hline & Dawn & Jang \\
\hline AVERAGE NEWS PER YEAR & 29.67 & 56 \\
\hline Event & $34.29 \% \%$ & $31.01 \%$ \\
\hline Statement & $31.68 \%$ & $55.31 \%$ \\
\hline Exclusive & $8.44 \%$ & Nil \\
\hline Is ethnicity a problem? & $34.40 \%$ & $26.99 \%$ \\
\hline Ethnic context & $16.03 \%$ & $19.82 \%$ \\
\hline Unity in diversity & $3.10 \%$ & $2.56 \%$ \\
\hline Two-nation theory & $1.71 \%$ & $9.71 \%$ \\
\hline \multicolumn{3}{|l|}{ Ethnic preference } \\
\hline Solution & $12.23 \%$ & $19.07 \%$ \\
\hline Community condemned & Nil & Nil \\
\hline \multicolumn{3}{|l|}{ Ethnic actors } \\
\hline Ethnic conflicts & $3.95 \%$ & $3.49 \%$ \\
\hline Ethnic relation & $1.33 \%$ & $2.54 \%$ \\
\hline Human touch & $4.27 \%$ & Nil \\
\hline Incitement to violence & Nil & Nil \\
\hline Quota condemned & Nil & Nil \\
\hline Mohajir integration & $3.63 \%$ & Nil \\
\hline Mohajir separatism & Nil & Nil \\
\hline Provincial autonomy condemned & Nil & Nil \\
\hline Provincial autonomy favoured & $1.71 \%$ & $3.33 \%$ \\
\hline Indian involvement & Nil & Nil \\
\hline Politics of ethnicity & $1.71 \%$ & $5.72 \%$ \\
\hline
\end{tabular}

Table 2

\section{CATEGORY SECOND}

\begin{tabular}{|l|c|c|}
\hline \multicolumn{3}{|c|}{$\begin{array}{c}\text { AGGREAGTE \% AGE ETHNIC ACTORS CATEGORY } \\
\text { FIRST 2007, 2008, 2009 }\end{array}$} \\
\hline & Dawn & Jang \\
\hline & 32.67 & 52.35 \\
\hline AVERAGEN NEWS PER YEAR & $27.29 \%$ & $\mathbf{9 . 5 5}$ \\
\hline Event & $\mathbf{1 4 . 3 1 \%}$ & $\mathbf{8 9 . 5 3}$ \\
\hline Statement & $\mathbf{5 9 . 7 5 \%}$ & $\mathbf{0 . 9 3}$ \\
\hline Exclusive & $\mathbf{3 2 . 1 2 \%}$ & $\mathbf{3 9 . 8 9}$ \\
\hline Is ethnicity a problem? & $\mathbf{2 6 . 1 5 \%}$ & $\mathbf{3 2 . 4 8}$ \\
\hline Ethnic context & $\mathbf{1 1 . 3 2 \%}$ & Nil \\
\hline Unity in diversity & $\mathbf{0 . 8 5 \%}$ & $\mathbf{1 4 . 8 9}$ \\
\hline Two-nation theory & & \\
\hline Ethnic preference & $\mathbf{4 0 . 5 3 \%}$ & $\mathbf{7 . 1 9}$ \\
\hline Solution & Nil & Nil \\
\hline Community condemned & & \\
\hline Ethnic actors & $\mathbf{0 . 8 5 \%}$ & $\mathbf{1 1 . 1 1}$ \\
\hline Ethnic conflicts & $5.42 \%$ & Nil \\
\hline Ethnic relation & $27.04 \%$ & Nil \\
\hline Human touch & Nil & Nil \\
\hline Incitement to violence & Nil & Nil \\
\hline Quota condemned & $34.45 \%$ & Nil \\
\hline Mohajir integration & Nil & Nil \\
\hline Mohajir separatism & Nil & Nil \\
\hline Provincial autonomy condemned & $30.34 \%$ & 7.41 \\
\hline Provincial autonomy favoured & Nil & Nil \\
\hline Indian involvement & $29.25 \%$ & 4.63 \\
\hline Politics of ethnicity & & \\
\hline
\end{tabular}

The same is the case in table 2, reflecting Category Second which contains those ethnic news content which is either generated by sources like news agencies/press releases or exclusive bylines. Urdu daily Jang in the Category Second carried a mammoth 89.5 aggregate percentage points of statement-based news against Dawn's only 14.31. However, if seen in the context of the Category First, there seems hardly any difference between Urdu and English dailies with regard to the placement of event-based ethnic news items with Urdu language Jang carrying 31.01 aggregate percentage points of 
event-based news, as table 1 shows, while Dawn carried a little more in 34.29 aggregate percentage points. The same is the pattern in Category Second depicted in table 2.

As for the exclusive coverage of ethnic discourse in the Category First-news items generated by reporters but having no bylines-Urdu daily Jang has failed to carry any exclusive ethnic news item, as shown in table 1 while Dawn has carried 8.44 aggregate percentage points of such ethnic news in the same category. Nonetheless, the English daily impresses with regard to the coverage of ethnic issues through exclusive news in the Category Second, containing ethnic news items generated through bylines and sources in shape of agencies and press releases. Considering the English daily's 59.75 aggregate percentage points of exclusive news in the Category Secondly, it can be easily said that the prestigious Dawn has performed its duties of a vanguard in English journalism in context of coverage of ethnic issues in the Sindh metropolis while the largest Urdu daily catering to a huge chunk of the population has by and large failed to carry any exclusive news regarding ethnic issues in Karachi in the Category Secondcontent generated by bylines and sources like agencies/press releases.

Getting down to important categories related to our aim of reaching any conclusions regarding the role of discourse in the national integration, the category 'Is ethnicity a problem?' in table 1, depicting data of Category First (content generated by reporters but without bylines), shows an increasing tendencies of newspapers towards realization of the fact that ethnicity is a problem with the English daily carrying 34.40 aggregate percentage points of such news while Jang is not far away in this regard giving place to 26.99 aggregate percentage points of such news. The code namely 'Is ethnicity a problem?' shows the same pattern in table 2 .

When the abovementioned figures were presented to editor of Dawn Zaffar Abbas during an interview conducted with regard to the research, he said: "If I could only talk about Dawn, the reason behind increase in such news items might be the increased number of references to ethnic identities which were earlier not disclosed in Dawn possibly due to the fact that it might lead to more violence. But now there has come a policy shift in Dawn coverage of ethnic news since now the daily feels no hesitation in disclosing the ethnic background of any group/individual involved in any ethnic conflict". ${ }^{30}$

As for code 'unity in diversity' which means 'whether the news items deal with ethnic affairs as an ethnic problem which needs to be dealt with through power-sharing deal,' though Dawn has fared well than the largest Urdu daily in Jang, coverage of both dailies in context of 'unity in diversity' has to be improved, considering over three and over two aggregate percentage points of ethnic news in the 'unity in diversity' context carried by Dawn and Jang respectively in the Category First (news content produced by reporters without bylines). Category Second depicted in table 2 shows the same trend.

On the other hand, Jang in the Category Second (content generated through bylines and sources in agencies/press) carried more ethnic news items depicting the code two-nation

${ }^{30}$ Zaffar Abbas, Personal interview, Dawn office, Karachi April 28, 2016. 
theory - which is about the discourse related to unity of peoples on the basis of the controversial two-nation theory which is against any other identity except for the Islamic one- by giving space to 14.89 aggregate percentage points of such ethnic items against almost nil carried by Dawn which carried a negligible 1.71 aggregate percentage of twonation theory-related ethnic news in the Category First (reporters' news without bylines) against a sizeable 9.71 percentage points of such discourse carried by Jang in the same category.

Getting down to categories 'ethnic actors' and 'ethnic preferences' of Category First and Category Second depicted in tables 3, 4, 5 and 6, Dawn mention of ethnic actors in the Category First (reporters' news without bylines) is more than Jang as depicted in table 3 while both dailies are almost the same regarding code of 'ethnic actors' (mentioning/naming ethnic actors) in the Category Second (content generated through bylines and sources in agencies/press) as depicted by table 5. With the Category First showing a meager aggregate percentage points of ethnic preference news as shown in table 4, the pattern depicted in table 6, showing Category Second, displays that Jang whose collective aggregate percentage points stand at 8.63 has shown a slant towards various ethnic groups. For more details look at tables 4 and 6.

Table 3

Category First [Reporters' content without bylines]

\begin{tabular}{|c|c|c|}
\hline \multicolumn{3}{|c|}{$\begin{array}{c}\text { AGGREAGTE \% AGE ETHNIC ACTORS } \\
\text { CATEGORY FIRST 2007, 2008, 2009 }\end{array}$} \\
\hline & \multicolumn{2}{|c|}{ NEWS } \\
\hline & Dawn & Jang \\
\hline Ethnic actors & $13.54 \%$ & $\mathbf{7 . 6 4 \%}$ \\
\hline Pakhtuns & $1.71 \%$ & $4.58 \%$ \\
\hline Mohajirs & $2.24 \%$ & $\mathbf{0 . 6 7 \%}$ \\
\hline Sindhis & $4.39 \%$ & Nil \\
\hline Biharis & Nil & Nil \\
\hline Punjabis & $2.24 \%$ & $1.19 \%$ \\
\hline Saraikis & Nil & Nil \\
\hline Balochs & $1.28 \%$ & Nil \\
\hline Memons & $1.71 \%$ & Nil \\
\hline Gujaratis & Nil & Nil \\
\hline Afghans & Nil & 0.85\% \\
\hline
\end{tabular}

Table 4

Category First [Reporters' content without bylines]

\begin{tabular}{|c|c|c|}
\hline \multicolumn{3}{|c|}{$\begin{array}{c}\text { AGGREAGTE \% AGE ETHNIC ACTORS } \\
\text { CATEGORY FIRST 2007, 2008, 2009 }\end{array}$} \\
\hline & \multicolumn{2}{|c|}{ NEWS } \\
\hline & Dawn & Jang \\
\hline Ethnic Preference & $3.63 \%$ & $3.76 \%$ \\
\hline Pakhtuns & Nil & $\mathbf{2 - 9 0 \%}$ \\
\hline Mohajirs & Nil & Nil \\
\hline Sindhis & $2.24 \%$ & Nil \\
\hline Biharis & Nil & Nil \\
\hline Punjabis & $1.39 \%$ & 0.85\% \\
\hline Saraikis & Nil & Nil \\
\hline Balochs & Nil & Nil \\
\hline Memons & Nil & Nil \\
\hline Gujaratis & Nil & Nil \\
\hline Afghans & Nil & Nil \\
\hline \multicolumn{3}{|c}{} \\
\end{tabular}


Table 5

Category Second [Content of agencies, press releases, bylines]

\begin{tabular}{|c|c|c|}
\hline \multicolumn{3}{|c|}{$\begin{array}{c}\text { AGGREAGTE \% AGE ETHNIC ACTORS } \\
\text { CATEGORY FIRST 07, 08, 09 }\end{array}$} \\
\hline & \multicolumn{2}{|c|}{ NEWS } \\
\hline & Dawn & Jang \\
\hline Ethnic actors & $\mathbf{7 . 1 0 \%}$ & $\mathbf{7 . 4 2 \%}$ \\
\hline Pakhtuns & $1.39 \%$ & $4.57 \%$ \\
\hline Mohajirs & $1.90 \%$ & Nil \\
\hline Sindhis & $1.90 \%$ & $\mathbf{0 . 9 5 \%}$ \\
\hline Biharis & Nil & Nil \\
\hline Punjabis & Nil & 0.95\% \\
\hline Saraikis & Nil & Nil \\
\hline Balochs & $1.90 \%$ & $0.95 \%$ \\
\hline Memons & Nil & Nil \\
\hline Gujaratis & Nil & Nil \\
\hline Afghans & Nil & Nil \\
\hline
\end{tabular}

Table 6 Category Second [Content of agencies, press releases, bylines]

\begin{tabular}{|c|c|c|}
\hline \multicolumn{3}{|c|}{$\begin{array}{c}\text { AGGREAGTE \% AGE ETHNIC ACTORS } \\
\text { CATEGORY FIRST 07, 08, 09 }\end{array}$} \\
\hline & \multicolumn{2}{|c|}{ NEWS } \\
\hline & Dawn & Jang \\
\hline Ethnic preference & Nil & $\mathbf{8 . 6 3 \%}$ \\
\hline Pakhtuns & Nil & $\mathbf{1 . 7 1 \%}$ \\
\hline Mohajirs & Nil & $\mathbf{2 . 0 8 \%}$ \\
\hline Sindhis & Nil & $\mathbf{3 . 8 9 \%}$ \\
\hline Biharis & Nil & Nil \\
\hline Punjabis & Nil & Nil \\
\hline Saraikis & Nil & Nil \\
\hline Balochs & Nil & $\mathbf{0 . 9 5 \%}$ \\
\hline Memons & Nil & Nil \\
\hline Gujaratis & Nil & Nil \\
\hline Afghans & Nil & Nil \\
\hline
\end{tabular}

\section{Role of National Newspapers in National Integration}

Though 22 codes have been developed, the researcher opts to shed light on only a few, considering shortage of space, to reach any conclusion regarding role of newspapers in the process of nation-building. It was found during the discourse analysis of both the dailies that there is a realization that ethnicity is a problem as almost over 30 aggregate percentage of points of ethnic news falling in code 'is ethnicity a problem?' in both Category First and Category Second have displayed. The acknowledgment that ethnicity is a problem is first step towards understanding ethnic problems which will definitely help in national integration. However, newspapers discourse has still a long way to go in context of the acknowledgment of the fact that Sindh capital in order to resolve its ethnic issues needs to adopt the policy of 'unity in diversity,' for ethnic news generated in both newspapers in this particular code is almost negligible, though Dawn in the Category Second (content generated through bylines and sources in agencies/press) faring well to place over 11 aggregate percentage points of such news. Notwithstanding, the overall figures related to 'unity in diversity' are not encouraging which may be a stumbling block in national integration.

The other important code having implications for the process of integration is 'twonation theory' which basically deals with news content promoting the state-supported narrative of one Islamic identity. Though Dawn in both categories carried negligible percentage points of news related to nationalistic rhetoric, Jang carried a sizeable percentage point of such news in both categories with the Urdu daily carrying almost 15 percentage points of such news items in Category Second (content generated through bylines and sources in agencies/press). 
Though readers could take any code to decide for themselves about the coverage of ethnic issues, it's once again repeated that space and time bars the researcher from shedding light on every code. Nonetheless, one important final code in 'human touch'meaning whether the discourse gives any clue about a reporter's awareness about the causes of migration which might be global warming, inter-state conflicts and natural calamities among others - cannot escape notice considering huge migrant population of Karachi descending from upcountry. There is simply no ethnic news item published in Jang which was written in the context of 'human touch' in the sampled time period in both Category First and Category Second. Nonetheless, Dawn has fared tremendously well publishing ethnic news written in the 'human touch' perspective in categories First and Second.

\section{Conclusion}

The realization in discourse that ethnicity is a problem (in Karachi) has got positive implications for integration. Dawn has no place for nationalistic rhetoric in shape of promotion of one Islamic identity which in turn may help in integration. If Dawn is any yardstick, English journalism seems willing to place discourse emanating unity in diversity. Also, English journalism has got insight into migration issues, for Dawn carried mammoth percentage points of 'human touch' news. Nonetheless, Dawn failed to carry a sizeable discourse emanating 'unity in diversity' which augers bad for integration. On the other hand, though discourse based on two-nation theory code is not huge in Jang, the daily is yet to wean itself off the narrative of oneness. Lastly, while Dawn has excelled in understanding the issues of migrants, Jang has hardly had any reporter having awareness of issues related to migration. In fact, Urdu discourse is completely devoid of views about root-causes of migration which may have dangerous implications for integration. 